\title{
Transferability of Simple Sequence Repeat (SSR) Markers Developed in Litchi chinensis to Blighia sapida (Sapindaceae)
}

\author{
Marius R. M. Ekué • Oliver Gailing • Reiner Finkeldey
}

Published online: 10 June 2009

(C) The Author(s) 2009. This article is published with open access at Springerlink.com

\begin{abstract}
Ackee (Blighia sapida, Sapindaceae) is a multipurpose fruit tree species of high economic importance, native to the Guinean forests of West Africa, and belongs to the same family as that of lychee (Litchi chinensis). In this study, a set of 12 primer pairs for simple sequence repeats (SSRs) previously developed for lychee has been evaluated for polymorphism in 16 ackee trees from different populations. Seven primer pairs have been found to be transferable, and four have revealed polymorphisms. However, the average number of alleles per locus has dropped from 4.9 for lychee to 3.7 for ackee. Characterization of the four polymorphic markers in 279 individuals belonging to14 different ackee populations from Benin has revealed that the numbers of alleles per locus range from two to 14 with a mean number of 5.8. The observed and expected heterozygosities range between 0.020 to 0.359 and 0.020 to 0.396 , respectively.
\end{abstract}

M. R. M. Ekué $(\bowtie) \cdot R$. Finkeldey

Department of Forest Genetics and Forest Tree Breeding,

Büsgen-Institute, Georg-August-Universität Göttingen,

Büsgenweg 2,

37077 Göttingen, Germany

e-mail: mekue@gwdg.de

e-mail: mrekue@gmail.com

\section{R. M. Ekué}

Laboratory of Applied Ecology, Faculty of Agronomic Sciences,

University of Abomey-Calavi,

01 BP 526 Cotonou, Benin

O. Gailing

School of Forest Resources \& Environmental Science,

Michigan Technological University,

1400 Townsend Drive,

Houghton, MI 49931, USA
Keywords Blighia sapida $\cdot$ Litchi chinensis .

Microsatellites · SSRs · Sapindaceae family $\cdot$ Transferability

$\begin{array}{ll}\text { Abbreviations } \\ \text { HWE } & \text { Hardy-Weinberg equilibrium } \\ \text { ICRAF } & \text { World Agroforestry Centre } \\ \text { LD } & \text { linkage disequilibrium } \\ \text { SSRs } & \text { simple sequence repeats } \\ \text { EST } & \text { expressed sequence tag } \\ \text { cDNA } & \text { complementary DNA }\end{array}$

\section{Introduction}

Ackee (Blighia sapida K. Konig) is a multipurpose fruit tree species native to the Guinean forests of West Africa. Although overlooked by researchers in the region, the tree is highly valued by farmers and is an important component of different agroforestry systems in Benin. Recently, ackee has emerged as a high-priority species for domestication in Benin after a national survey and ranking of nontimber forest products (Codjia et al. 2003). B. sapida is widely cultivated in Jamaica where it has been introduced during the eighteenth century (ICRAF 2008) with an annual turnover of approximately $\$ 400$ million in 2005 for the trade of arils of fruits (Pen 2006). Seeds and capsules of fruits are used for soap-making and for fishing, and all parts of the tree have medicinal uses (Ekué et al. 2004, Dossou et al. 2004; Ekué 2005).

To develop strategies for domestication and sustainable management of this species, information on the level of genetic variation and the extent of genetic diversity within and between natural and managed populations is vital. The development of microsatellites or simple sequence repeats (SSRs) provides an ideal tool to investigate genetic variation patterns due to their 
codominant, multiallelic, and highly polymorphic properties. However, given the time-consuming and expensive process of isolating SSRs, it is advantageous to utilize primer sequences already identified in one species in other closely related species. Cross-species amplification and utility of molecular markers depend on the conservation of priming sites within flanking sequences and on the maintenance of arrays long enough to promote polymorphisms (FitzSimmons et al. 1995). Several studies have demonstrated the utility of using primer pairs designed from one species to other species of the same genus (Rallo et al. 2003; Pandey et al. 2004; Mottura et al. 2005; Takayama et al. 2008) and even to species of other genera (e.g., White and Powell 1997; Zucchi et al. 2002; Viruel and Hormaza 2004; Barreneche et al. 2004). Cross-species amplification was previously reported in longan (Euphoria longan (Lour.) Steud.) and pulasan (Nephelium rambutan-ake L.), both belonging to the subfamily Nepheleae as lychee (Viruel and Hormaza 2004; Sim et al. 2005).

In this study, cross-species transferability of 12 SSRs developed for Litchi chinensis Sonn. (Viruel and Hormaza 2004) to a new target species, B. sapida, belonging to the Sapindoideae subfamily was investigated.

\section{Materials and Methods}

\section{Plant Material and DNA Analysis}

Leaves were collected from 279 individual trees from 14 natural and planted populations covering the whole range of the species in Benin (between $6^{\circ} 54^{\prime}$ to $11^{\circ} 09^{\prime} \mathrm{N}$ and $0^{\circ} 59^{\prime}$ to $3^{\circ} 28^{\prime}$ E) and dried in silica gel.

Total genomic DNA was extracted from $\sim 1 \mathrm{~cm}^{2}$ of dried leaf tissue using a DNeasy ${ }^{\circledR}$ Plant Kit (Qiagen, Hilden, Germany) and adding up to $2.6 \%$ polyvinylpyrrolidone $\mathrm{K} 30$ to the AP1 lysis buffer. Polymerase chain reaction (PCR) amplification was conducted in a $10-\mu \mathrm{L}$ volume containing $1 \mu \mathrm{L}$ of genomic DNA (10 ng), $5 \mu \mathrm{L}$ of HotStarTaq Master Mix, 0.1 U/ $\mu \mathrm{L}$ Taq DNA polymerase, $3 \mathrm{mM} \mathrm{MgCl}_{2}, 400 \mu \mathrm{M}$ dNTPs (Qiagen, Hilden, Germany), and 5 pmol of each primer. The PCR protocol consisted of an initial denaturation step of $95^{\circ} \mathrm{C}$ for $15 \mathrm{~min}$, followed by 35 cycles of $94^{\circ} \mathrm{C}$ for $30 \mathrm{~s}$, annealing for $1 \mathrm{~min}, 72^{\circ} \mathrm{C}$ for $1 \mathrm{~min}$, and a final extension step of $72^{\circ} \mathrm{C}$ for $10 \mathrm{~min}$. For primers LMLY4 and LMLY6, the duration of denaturation and annealing during 35 cycles was $1 \mathrm{~min}$. All PCRs were conducted in a Peltier Thermal Cycler (PTC-200 version 4.0, MJ Research).

Amplified products were resolved electrophoretically on an ABI Genetic Analyzer 3100 together with an internal size standard GeneScan 500 ROX (fluorescent dye ROX) from Applied Biosystems. Fragment sizes were determined using software packages GENESCAN 3.7 and GENOTYPER 3.7 (Applied Biosystems).

The sequences of all 12 lychee primer pairs used are presented in Table 1. A total of 16 ackee genotypes from different populations were initially used to evaluate the amplification and polymorphisms of these lychee primer pairs, and those markers found to be polymorphic were then used to amplify all trees.

Table 1 Transferability of 12 SSR markers from L. chinensis to B. sapida

\begin{tabular}{|c|c|c|c|c|c|c|c|c|c|c|}
\hline \multirow{2}{*}{$\begin{array}{l}\text { SSR } \\
\text { marker }\end{array}$} & \multirow[t]{2}{*}{ Repeat type } & \multicolumn{2}{|c|}{ Presence of } & \multirow[t]{2}{*}{$T_{\mathrm{a}}\left({ }^{\circ} \mathrm{C}\right)$} & \multicolumn{3}{|c|}{ Number of alleles } & \multicolumn{3}{|c|}{ Allele size range (bp) } \\
\hline & & $\begin{array}{l}\text { PCR } \\
\text { band }\end{array}$ & Polymorphism & & $\begin{array}{l}\text { Litchi } \\
\text { chinensis }\end{array}$ & $\begin{array}{l}\text { Blighia } \\
\text { sapida }\end{array}$ & $\begin{array}{l}\text { Nephelium } \\
\text { rambutan- } \\
\text { ake }\end{array}$ & $\begin{array}{l}\text { Litchi } \\
\text { chinensis }\end{array}$ & $\begin{array}{l}\text { Blighia } \\
\text { sapida }\end{array}$ & $\begin{array}{l}\text { Nephelium } \\
\text { rambutan- } \\
\text { ake }\end{array}$ \\
\hline LMLY1 & $(\mathrm{CT})_{11} \mathrm{TT}(\mathrm{CT})_{5}$ & No & No & - & 10 & - & - & $132-214$ & - & - \\
\hline LMLY2 & $(\mathrm{GA})_{8}$ & No & No & - & 8 & - & 3 & $154-183$ & - & $154-168$ \\
\hline LMLY3 & $(\mathrm{GA})_{18}$ & Yes & No & 48 & 3 & 1 & - & $178-190$ & 156 & - \\
\hline LMLY4 & $\mathrm{GAA}(\mathrm{GA}) \mathrm{GG}(\mathrm{GA})_{4}$ & Yes & Yes & 45 & 4 & 2 & 1 & $204-210$ & $182-183$ & 182 \\
\hline LMLY5 & $(\mathrm{GA})_{9}$ & Yes & Yes & 50 & 5 & 14 & 1 & $280-304$ & 289-315 & 290 \\
\hline LMLY6 & $(\mathrm{GA})_{9}(\mathrm{CA})_{2}(\mathrm{GA})_{4}$ & Yes & Yes & 39.4 & 3 & 2 & 4 & $146-154$ & $122-135$ & $132-154$ \\
\hline LMLY7 & $(\mathrm{CT})_{17}$ & Yes & Yes & 50 & 7 & 5 & 1 & $216-238$ & $241-247$ & 240 \\
\hline LMLY8 & $(\mathrm{GA})_{9}$ & Yes & No & 48 & 4 & 1 & 1 & $288-302$ & 282 & 285 \\
\hline LMLY9 & $(\mathrm{GA})_{3} \mathrm{GGGAA}(\mathrm{GA})_{9}$ & No & No & - & 3 & - & - & $92-96$ & - & - \\
\hline LMLY10 & $(\mathrm{CT})_{11} \mathrm{TT}(\mathrm{CT})_{5}$ & No & No & - & 6 & - & - & $312-342$ & - & - \\
\hline LMLY11 & $(\mathrm{GA})_{4} \mathrm{GGAA}(\mathrm{GA})_{2} \mathrm{G}(\mathrm{GA})_{4}$ & No & No & - & 2 & - & - & $155-156$ & - & - \\
\hline LMLY12 & $(\mathrm{CT})_{11}$ & Yes & No & 48 & 4 & 1 & 3 & 204-209 & 203 & $195-217$ \\
\hline
\end{tabular}

All lychee SSRs were developed from a genomic DNA library enriched in CT repeats. Annealing temperature $\left(T_{\mathrm{a}}\right)$ for ackee, the number of alleles, and the allele size range for L. chinensis and N. rambutan-ake are adopted from Viruel and Hormaza (2004) and Sim et al. (2005), respectively 
Table 2 Amplification frequency of $L$. chinensis SSR markers across three species of the Sapindaceae family

\begin{tabular}{lcccccc}
\hline \multirow{2}{*}{ Species } & \multicolumn{2}{l}{ Successful amplification of lychee primers } & & \multicolumn{2}{l}{ Polymorphic lychee SSR markers } & \multirow{2}{*}{ Source } \\
\cline { 2 - 3 } & Number & Percent & & Number & Percent & \\
\hline Blighia sapida & 7 & 58.3 & & 4 & 57.1 & This study \\
Nephelium rambutan-ake & 7 & 58.3 & & 3 & 42.9 & Sim et al. (2005) \\
Euphoria longan & 11 & 91.7 & & 8 & 72.7 & Viruel and Hormaza (2004) \\
Litchi chinensis & 12 & 100 & 12 & 100 & \\
\hline
\end{tabular}

Data Analysis and Interpretation

An SSR marker was deemed transferable if the amplification of a PCR band of the expected size was observed (GonzálezMartinez et al. 2004). The program MICRO-CHECKER (van Oosterhout et al. 2004) was used to check for scoring errors, allele dropouts, and null alleles. Observed $\left(H_{\mathrm{O}}\right)$ and expected $\left(H_{\mathrm{E}}\right)$ heterozygosity were computed for each polymorphic locus. Deviation from Hardy-Weinberg equilibrium (HWE) and linkage equilibrium were tested for all loci using GENEPOP 3.4 (Raymond and Rousset 1995). Diversity parameters were computed separately for natural and planted stands of ackee.

\section{Results and Discussion}

\section{SSR Transferability}

Out of 12 lychee primer pairs tested, seven yielded amplification products of expected sizes (58.3\%; Table 2). A similar frequency of amplification was observed in $N$. rambutan-ake (Sim et al. 2005), while a higher frequency was observed in E. longan (91.7\%; Viruel and Hormaza 2004) using the same set of primers.

This frequency of cross-genus transferability of SSR loci within the Sapindaceae family is much higher than that, $2.9 \%$ of 346 primer pairs, observed in the Myrtaceae family, from Eucalyptus spp. to Eugenia dysenterica. It is within the range $(36.4 \%$ to $63.6 \%)$ observed in the Meliaceae family (from Switenia humilis to six different genera; White and Powell 1997; Zucchi et al. 2002). Similar to the presented results, transferability of SSRs developed in Quercus robur to Castanea sativa and vice versa within the Fagaceae family was possible with $47 \%$ (25) of the Quercus SSRs and 63\% (19) of the Castanea SSRs showing amplification products in the nonsource species (Barreneche et al. 2004).

In general, cross-species transferability differs highly among taxa especially in flowering plants. It seems to be highest in species with long generation time and with an outcrossing breeding system like B. sapida (Barbará et al. 2007).
Among all 12 primer pairs tested, 11 were deemed simple markers and one (LMLY6) was deemed a compound marker (Table 1; Viruel and Hormaza 2004). Among those 11 simple SSRs, six were perfect and five were imperfect markers. Five of the six perfect markers and only one of the imperfect SSRs were transferable to ackee. A similar finding was observed in pulasan (Table 1) as reported by Sim et al. (2005). This apparent association between transferability and perfectness of the repeat sequence was previously suggested by Kutil and Williams (2001). It was reported that markers based on imperfect repeats were likely to be less conserved than those harboring perfect repeats as the "death" of a microsatellite was accompanied by the accumulation of interruptions and/or large deletions, and thus compound SSRs could, therefore, represent a late stage in microsatellite evolution.

Among those seven transferable lychee SSR markers to B. sapida, four were polymorphic $(57.1 \%)$, while only three out of seven $(42.9 \%)$ were polymorphic for $N$. rambutanake and eight out of $11(72.7 \%)$ were polymorphic for $E$. longan (Table 2). When transferring $346 \mathrm{SSRs}$ from Eucalyptus spp. to E. dysenterica, the percentage of polymorphic loci dropped to $70 \%$ (Zucchi et al. 2002). Rosetto (2001) summarized data from 19 studies and found that $58 \%$ of microsatellites were polymorphic within the same family and $78 \%$ within the same subgenus. Therefore, the results obtained in this study were within the range reported previously.

Table 3 Characteristics of four polymorphic SSR markers in $B$. sapida

\begin{tabular}{|c|c|c|c|c|c|c|}
\hline \multirow[t]{2}{*}{ Locus } & \multicolumn{3}{|c|}{ Natural stands $(n=109)$} & \multicolumn{3}{|c|}{ Planted stands $(n=170)$} \\
\hline & $N_{\mathrm{a}}$ & $H_{\mathrm{O}}$ & $H_{\mathrm{E}}$ & $N_{\mathrm{a}}$ & $H_{\mathrm{O}}$ & $H_{\mathrm{E}}$ \\
\hline LMLY4 & 2 & 0.149 & 0.137 & 2 & 0.082 & 0.095 \\
\hline LMLY5 & 13 & 0.359 & 0.396 & 10 & 0.328 & 0.364 \\
\hline LMLY6 & 2 & 0.020 & 0.020 & 2 & 0.078 & 0.071 \\
\hline LMLY7 & 5 & 0.084 & 0.103 & 5 & 0.064 & 0.062 \\
\hline
\end{tabular}

$N_{a}$ number of alleles, $H_{O}$ observed heterozygosity, $H_{E}$ expected heterozygosity 
In this study, a total of 26 alleles has been detected (3.7 alleles per marker). This is lower than those 59 alleles detected in lychee ( 4.9 alleles per marker), but considerably higher than those 14 alleles observed in N. rambutan-ake (two alleles per marker). In general, both numbers of alleles per locus and allele size were lower in ackee than in lychee, but with a few exceptions. The number of alleles obtained with SSR marker LMLY5 in ackee is three times that found in lychee, and sizes of alleles obtained with SRR markers LMLY5 and LMLY7 are higher in ackee than in lychee (Table 1).

The relatively high frequency of cross-transferability observed in this study is rather unexpected as ackee belongs to the Sapindoideae subfamily, while lychee, pulasan, and longan belong to the subfamily Nepheleae and are, therefore, more closely related. It is known that microsatellites derived from expressed sequence tags (ESTs), complementary DNA, and low-copy or undermethylated DNA libraries are more conserved and exhibit higher transferability than those derived from noncoding regions (Shepherd et al. 2002). In this study, lychee SSRs have been developed from a genomic DNA library enriched in CTs and are, therefore, expected to display lower frequencies of transferability compared to EST-SSRs. However, it has been previously reported that the conserved nature of SSRs derived from coding regions limits their observed levels of polymorphisms (Shepherd et al. 2002).

\section{Characterization of Polymorphic Markers}

Genetic variation estimates of the four polymorphic loci detected in this study are listed in Table 3. In natural stands of ackee, observed and expected heterozygosities ranged from 0.020 to 0.359 and from 0.020 to 0.396 , respectively. Higher numbers of alleles were detected in natural stands (from two to 13 with a mean of 5.5) than in planted stands (from two to ten with a mean of 4.8) of ackee. Moreover, there was also a drop in both $H_{\mathrm{O}}$ and $H_{\mathrm{E}}$ in planted stands for all detected loci, except for LMLY6. A significant deviation from the HWE was observed in two natural stands of ackee, in Pobe for locus LMLY5 $(P=0.007)$ and in Adjahonmey for locus LMLY7 $(P=0.017)$. For a single planted stand (Kandi), deviation from HWE was observed for locus LMLY5 $(P=0.009)$. Presence of null alleles, attributed to excess of homozygotes for most allele size classes, were detected for loci LMLY5 in Kandi and LMLY7 in Adjahonmey. This might explain the observed deviation from HWE for the Adjahonmey stand. Linkage disequilibrium among markers was significant $(P<0.05)$ between LMLY4 and LMLY5 in a single planted stand (Glazoue) and between LMLY5 and LMLY7 in a single natural stand (Adjahonmey).

In summary, these findings provide additional evidence for the potential transferability of SSRs across genera.
Previous studies covering many plant families have revealed that generally only a low percentage of markers amplify fragments from species belonging to different genera (Weising et al. 2005). The relatively high percentage of cross-transferability of lychee SSR markers to ackee observed in this study renders these markers useful for investigating the genetic diversity and structure of B. sapida populations.

Acknowledgements This research was supported by a grant from the International Foundation for Science (IFS), Stockholm, Sweden and a scholarship from the Katholische Akademische AusländerDienst (KAAD), Bonn, Germany to Marius R.M. Ekué. We appreciate the laboratory assistance of Oleksandra Dolynska.

Open Access This article is distributed under the terms of the Creative Commons Attribution Noncommercial License which permits any noncommercial use, distribution, and reproduction in any medium, provided the original author(s) and source are credited.

\section{References}

Barbará T, Palma-Silva C, Paggi GM, Bered F, Fay MFC, Lexer C (2007) Cross-species transfer of nuclear microsatellite markers: potential and limitations. Mol Ecol 16(18):3759-3767. doi:10.1111/j.1365294X.2007.03439.x

Barreneche T, Casasoli M, Russell K, Akkak A, Meddour H, Plomion C, Villani F, Kremer A (2004) Comparative mapping between Quercus and Castanea using simple-sequence repeats (SSRs). Theor Appl Genet 108:558-566. doi:10.1007/s00122-003-1462-2

Codjia JTC, Assogbadjo AE, Ekué MRM (2003) Diversité et valorisation au niveau local des ressources végétales forestières alimentaires du Bénin. Cah Agric 12:321-331

Dossou MKR, Codjia JTC, Biaou G (2004) Utilisations, fonctions et perceptions de l'espèce-ressource Blighia sapida (ackee ou faux acajou) dans le Nord-Ouest du Bénin. Bull Rech Agron Benin 45:17-28

Ekué MRM (2005) Genetic variability and sustainable utilisation of Blighia sapida K. Konig in Benin. Final Technical Report, Bioversity International/LEA, $59 \mathrm{p}$

Ekué MRM, Assogbadjo AE, Mensah GA, Codjia JTC (2004) Aperçu sur la distribution écologique et le système agroforestier traditionnel autour de l'ackée (Blighia sapida) en milieu soudanien au Nord Bénin. Bull Rech Agron Benin 44:34-44

FitzSimmons NN, Moritz C, Moore S (1995) Conservation and dynamics of microsatellite loci over 300 million years of marine turtle evolution. Mol Biol Evol 12:432-440

González-Martinez SC, Robledo-Arnuncio JJ, Collada C, Díaz A, Williams CG, Alía R, Cervera MT (2004) Cross-amplification and sequence variation of microsatellite loci in Eurasian hard pines. Theor Appl Genet 109:103-111. doi:10.1007/s00122-004-1596-x

ICRAF (International Centre for Research in Agroforestry). Available from http://www.worldagroforestry.org/Sites/TreeDBS/aft/species PrinterFriendly.asp? Id=17953. Accessed 15 December 2008

Kutil BL, Williams CG (2001) Triplet-repeat microsatellites shared among hard and soft pines. J Heredity 92:327-332. doi:10.1093/ jhered/92.4.327

Mottura MC, Finkeldey R, Verga AR, Gailing O (2005) Development and characterisation of microsatellite markers for Prosopis chilensis and Prosopis flexuosa and cross-amplification. Mol Ecol Notes 5:487-489. doi:10.1111/j.1471-8286.2005.00965.x 
Pandey M, Gailing O, Fischer D, Hattemer HH, Finkeldey R (2004) Characterisation of microsatellites markers in sycamore (Acer pseudoplatanus L.). Mol Ecol Notes 4:253-255. doi:10.1111/ j.1471-8286.2004.00633.x

Pen M, Jamaica Information Service (2006) Viable ackee industry must be protected-BSJ inspector. Available at http://www.jis. gov.jm/agriculture/html/20060506T100000-0500_8777_JIS_ VIABLE ACKEE INDUSTRY MUST BE PROTECTEDD BSJ INSPECTOR.asp. Accessed 15 December 2008.

Rallo P, Tenzer I, Gessler C, Baldoni L, Dorado G, Martín A (2003) Transferability of olive microsatellite loci across the genus Olea. Theor Appl Genet 107:940-946. doi:10.1007/s00122-003-1332-y

Raymond M, Rousset F (1995) GENEPOP (version 1.2): population genetics software for exact tests and ecumenicism. J Heredity $86: 248-249$

Rosetto M (2001) Sourcing of SSR markers from related plant species, in plant genotyping. In: Henry RJ (ed) The DNA fingerprinting of plants. CABI, Wallingford, UK, pp 211-224

Shepherd M, Cross M, Maguire TL, Dieters MJ, Williams CG, Henry RJ (2002) Transpecific microsatellites for hard pines. Theor Appl Genet 104:819-827. doi:10.1007/s00122-001-0794-z

Sim CH, Mahani MC, Choong CY, Salma I (2005) Transferability of SSR markers from lychee (Litchi chinensis Sonn.) to pulasan
(Nephelium ramboutan-ake L.). Fruits 60:379-385. doi:10.1051/ fruits:2005043

Takayama K, Tamura M, Tateishi Y, Kajita T (2008) Isolation and characterization of microsatellite loci in the red mangrove Rhizophora mangle (Rhizophoraceae) and its related species. Conserv Genet 9:1323-1325. doi:10.1007/s10592-007-9475-z

Van Oosterhout C, Hutchinson WF, Wills DP, Shipley P (2004) Microchecker: software for identifying and correcting genotyping errors in microsatellite data. Mol Ecol Notes 4:535-538. doi:10.1111/ j.1471-8286.2004.00684.x

Viruel MA, Hormaza JI (2004) Development, characterization and variability analysis of microsatellites in lychee (Litchi chinensis Sonn., Sapindaceae). Theor Appl Genet 108:896-902. doi:10.1007/s00122-003-1497-4

Weising K, Nybom H, Wolff K, Kahl G (2005) DNA fingerprinting in plants: principles, methods, and applications, 2nd edn. CRC, Boca Raton

White G, Powell W (1997) Cross-species amplification of SSR loci in the Meliaceae family. Mol Ecol 6:1195-1197. doi:10.1046/ j.1365-294X.1997.00297.x

Zucchi MI, Brondani RPV, Pinheiro JB, Brondani C, Vencovsky R (2002) Transferability of microsatellite markers from Eucalyptus spp. to Eugenia dysenterica (Myrtaceae family). Mol Ecol Notes 2:512-513. doi:10.1046/j.1471-8286.2002.00297.x 